European journal of American studies

11-1| 2016

Special Issue: Intimate Frictions: History and Literature in the United States from the 19th to the 21 st Century

\title{
Introduction: Encounters
}

Hélène Quanquin and Cécile Roudeau

\section{OpenEdition}

\section{Journals}

Electronic version

URL: https://journals.openedition.org/ejas/11407

DOI: $10.4000 /$ ejas. 11407

ISSN: 1991-9336

Publisher

European Association for American Studies

\section{Electronic reference}

Hélène Quanquin and Cécile Roudeau, "Introduction: Encounters", European journal of American studies [Online], 11-1 | 2016, document 1, Online since 02 June 2016, connection on 08 July 2021. URL: http:// journals.openedition.org/ejas/11407 ; DOl: https://doi.org/10.4000/ejas.11407

This text was automatically generated on 8 July 2021 .

Creative Commons License 


\title{
Introduction: Encounters
}

\author{
Hélène Quanquin and Cécile Roudeau
}

For Naomi Wulf

1 Encounters are both the object and form of this special issue of The European Journal of American Studies. Edited by a historian and a literary scholar of the United States trained in France, ${ }^{i}$ this issue is designed as a place of encounter and simultaneously takes "encounter" as an analytical object in itself, specifically the articulation or disarticulation between the disciplines of literature and history, the intersection between aesthetics and politics, and the dialogue between historical versions of the past and their literary reenactment. By arranging these encounters across the Atlantic and across disciplines, we have not tried to round off angles or to deemphasize the singularities of approaches, and certainly not to erase differences in methods honed over centuries. To the contrary, building on the old French term encontre, meaning "meeting; fight; opportunity," we hope to attend to frictions, tensions, and disagreements. ii

2 Responding to historian Eric Slauter's assessment of the growing "trade deficit" in literary studies when it comes to the transactions between history and literature in transatlantic and early American studies (153), Elizabeth M. Dillon noted that while "historians and literary scholars should read one another's work," and while "they have much to learn from one another," "the gap between the two does not need to be bridged so much as attended to: we need to mind (or mine) the gap, not to erase the different methodologies and aims that generate divergent scholarship in the field of Atlantic studies" (210). Like Dillon, we believe that there is a productivity of difference when it refuses to be mired in mutual exclusion. Away from the impasses of such binaries as textualism v. contextualism, historicism v. (new) formalism and presentism, this special issue rather speculates on contingent crossings, unsettling combinations which we understand not as the foundation of a new methodology but as a series of ad hoc responses to specific questions raised by specific texts and objects and the ways they are read today.

3 In doing so we are hardly the first to question the vexing and alluring relationship between history and literature in the United States. Following Slauter and his (no doubt 
deliberately) mixed metaphors, the economic stakes of such disciplinary unbalance have repeatedly been intertwined with the vocabulary of desire and frustration. When considered over time, the affective politics of cross-encounters proves anything but casual; it has nourished the steady yet tumultuous relationship, the intimate frictions between the disciplines from their infancy until the present day. As Hélène Cottet shows in her essay for this special issue, conversations between the two disciplines in the United States have a long history, which originated in "the institutionalization of interdisciplinarity as a counter-proposition to the specializing trend then advocated in American research universities" and the promotion of literature as a site of "generalist" scholarship in the early decades of the twentieth century. Harvard's History and Literature program, created 110 years ago, was its first concentration but the persistence of this interdisciplinary model is still evident in another program studied by Cottet, the Master of Arts program in History and Literature at Columbia University in Paris created in September 2011 in collaboration with two French partner institutions, the École des hautes études en sciences sociales and the École normale supérieure (Cottet).

4 In France, where the fault-line between the disciplines falls differently than in the United States, the encounter between history and literature-which is also the product of a turbulent disciplinary history (Pouly)-has recently sparked new debates and provocative manifestos. In 2010, in the wake of a strong interdisciplinary turn in the French academia, the historians of the Annales. Histoire, Sciences Sociales revisited the articulation between history and (literary) fiction after French and American historians, Paul Veyne and Hayden White among others, had planted a "hermeneutics of suspicion" (Ricoeur 27) at the heart of the historical discipline. Unlike Veyne and White, however, Etienne Anheim and Antoine Lilti, the editors of the 2010 issue of the Annales entitled Savoirs de la littérature ("What Literature Knows"), did not aim at reassessing the amount of fiction and the lure of narration that was unmistakably part of the historian's discourse; rather, the issue examined the extent to which literature might be a reservoir of knowledge, and of historical knowledge in particular. The editors' purpose was to overcome for good the watertight separation between those who were interested in texts (the literary scholars) and those who took the institutions, the social and political history of the book, of reading or publishing, as their object. What if, they asked, literature for the historian were something else than a piece of evidence, or a dubious representation? What if there were a literary mode of writing history, and, more important still, a literary manner of getting to know the past? Intersecting the questions raised by a 2009 issue of the French Review of American Studies (Derail and Monfort), which proposed to read U.S. history not so much as the object but as the product of literary fictions that never could, nor would, distinguish between the experience and the performance of the past, Anheim and Lilti, focusing on the French scene, were concerned with the literary experience of the past as one modality of constructing history.

5 This blurring of limits, this questioning of disciplinary categories not only prevails today in France, but has recently been the object of renewed investigation and experimentation. In 2013, an international conference, entitled "Littérature et histoire en débats" (Literature and History: New Debates) revisited the question of the "proximity" between literary writing and history (and historiography) in the political and epistemological and polemical context of the day marked by a renewed interest in archives and the notion of testimony in the work of historians, as well as literary 
scholars and writers of fiction.iii Emerging from these debates, books and edited collections have attempted to put such examinations into practice. Quentin Deluermoz and Anthony Glinoer's L'insurrection entre histoire et literature (1789-1914) (2015), for example, focused on the mutual impact of insurrections on literary writing and, in turn, of literature on the insurrectionary time. On the other hand, Ivan Jablonka's essay L'histoire est une littérature contemporaine (2014) proposed to take up the challenge of an encounter between history and literature, and cross literature as a possibility of writing (for the historian) and history as a possibility of knowing (for the writer). He invited scholars, on whichever side they dwelled, to embrace both possibilities, challenge the old disciplinary divides and experiment with what he calls "creative history." The provocation did not go unnoticed, in France at least. And yet, however much these publications attempted not to be trapped in a national paradigm, they rarely touched on the specificities of an American context and practice.

6 This special issue of EJAS has found its impulse in these debates, which have impacted our practices in different ways on both sides of the Atlantic and made the necessity of encounter more palpable still. In France, where the explication de texte remains one of the main competencies assessed in literary curricula and continues to inform literary scholarship to this day, historicism still somehow rings offensive, while the institutionalization of "civilization" has not fully succeeded in creating an "interdiscipline" (Allen and Kitch 281). iv In the United States, following a questioning of historicism among literary scholars, which Jennifer Fleissner has called "historicism blues" (Fleissner), and an increasing distrust, among U.S. historians, of literary epistemologies, reading practices are more than ever the target of scholars on either side of the disciplinary divide. ${ }^{v}$ This may be why renewed attention is being paid to what it means to read as a historian, as a literary scholar, and even as both.

7 This issue of the EJAS falls within this context and proposes to attend once again to forms of close reading, not, however, as a timeworn tactic targeted against history in the name of a textualist ideology but rather, in the words of Peter Coviello, as "a way of thickening history: of expanding the range of stories we tell about a place or text or concept, of trying out an expanded repertoire of conceptual possibilities" (Quanquin and Roudeau). To "thicken history"-isn't this precisely what both literary scholars and historians do when they read one another, when they accept to be unsettled by one another's readings? To test this hypothesis, we have therefore asked French and American historians and literary scholars of the United States to read forms, objects, and texts that could be viewed as concrete crystallizations of the dialogue between literature as a mode of writing and institutional practice and history as a series of bygone events, narrative, and process. A periodical like the Crisis, nineteenth-century suffrage literature, a poet's historical gesture (Williams Carlos Williams' In the American Grain), and a novelist's rewriting of black history from the present of Toni Morrison's "Black Matters" (Mat Johnson's Pym) are the hybrid objects close-read here by scholars who have agreed to play along and be slightly deported from their usual objects for the sake of this conversation. Attending to these objects that could be "both history and literature" (Jablonka 7), these essays revisit the American history of history and literature as disciplines. Because they are concrete attempts at reading across, they gesture towards a practice of literature and history as "interdisciplines" and incite us to think "out of the disciplinary box" today. 
8 "From One Crisis to the Other: History and Literature in The Crisis from 1910 to the Early 1920s" investigates the interaction between literature, news-reporting and history in the organ of the National Association for the Advancement of Colored People over one decade or so. TheCrisis, founded by W.E.B. Du Bois, was not a literary magazine but, as Lamia Dzanouni, Hélène Le Dantec-Lowry, and Claire Parfait show, within its format literature coexisted with history and "was always present under one form or another," sometimes on the margins, in advertisements, political essays, and illustrations, in keeping with its "format of intermediality." Examining the "internal dialogics" of the periodical (Ardis 38), the authors show that literature was used in its different forms as a political tool to promote the elevation and the political consciousness of the black race (Dzanouni, Le Dantec-Lowry and Parfait).

9 The suffrage novels, plays, and poems studied by Claire Delahaye also provide an example of ways in which literature intersected with history and politics at the turn of the twentieth century. In “'A Tract in Fiction:' Woman Suffrage Literature and the Struggle for the Vote," Claire Delahaye argues that, although suffrage literary productions have often been underrated by historians and literary scholars, they should be considered as important "political acts, cultural texts and historical sources." Testifying to the "creativity" of their authors, they "partook to the creation of suffragists' culture" and "functioned as compensatory modes of political expression to assert women's power" (Delahaye).

10 But literature is not only used as a political tool in editorial policies, nor does it serve only as a source for the historians who consider it as part of their scholarly explorations; as Delahaye's essay suggests, literature also questions the very practice of historical reading. To borrow from Dominick LaCapra's introduction to History, Literature, Critical Theory, "historical understanding is challenged by critical (including literary) theories, and literary criticism is not only informed but insistently interrogated by historical questions" (1). The following two articles, written by literary scholars, may be read as instances of how history as object, context, and narration, unsettles literary criticism as well.

11 Revisiting Claire Delahaye's assumption that literary modernism can be a powershifting force and an opportunity for alternative voices to be heard, Antonia Rigaud's essay reflects on the writing of history in the modernist context through the study of William Carlos Williams' In the American Grain (1925). Williams' historical project, Rigaud argues in "A Phosphorous History: William Carlos Williams' In the American Grain," turned history into a literary question. As a poet, Williams put language and form at the center of his historical project, not because of a belief, as Hayden White would say many years later, that history is literature, but because language is what has shaped the national imagination. Through a poetic reshuffling of voices, canonical and otherwise, through a collage of different narratives and perspectives, Williams sought to make history by capturing its evanescent reality-"the strange phosphorus of the life"-and correlated the lyrical and the historical in what may be regarded as a modernist biography of the American cultural imagination (Rigaud).

12 The last essay in this special issue, "Black Matters': Race and Literary History in Mat Johnson's Pym," by Jennifer Wilks, reconsiders the inextricable relationship between literary text and social context(s) through a study of Johnson's satirical novel Pym (2011). Read together with Edgar Allan Poe's The Narrative of Arthur Gordon Pym of Nantucket (1838) but also in the light of Toni Morrison's Playing in the Dark and the Black 
Lives Matter movement, Johnson's multi-layered neo-slave narrative, Wilks contends, encourages its readers to take a long view of history. Using satire to confront the paradoxes of his own historical moment, Johnson reveals the degree to which the nation's racist past reverberates in the lives of his cast of characters. In the end, it is not Poe that matters in Johnson's literary fiction, as much as the troubled, underexamined historical continuum between Poe's antebellum U.S. and the "colorblind" nation of Johnson's protagonists (Wilks).

13 How literary works of fiction manage to unsettle their reader's sense of history; how history itself, as narrative, comes to be questioned by literature, is ultimately what has interested us in this special issue. With the hope of furthering the dialogue between European and American scholars of U.S. literature, we end this issue with an interview with Peter Coviello, whose work has been central to the unsettling of disciplinary borders both topically and methodologically. Our digital transatlantic encounter has reproduced elements of his intellectual and personal trajectory in dialogue with the articles and the larger project presented here. Intrigued by our starting point-the contrasted construction of the two disciplines of history and literature in France and in the U.S., as analyzed in part by Hélène Cottet in the opening essay-Coviello provides precisely the kind of "encounter" we hope will feed the conversations between scholars, and across disciplines and national and historical traditions, that are so sorely needed.

\section{BIBLIOGRAPHY}

Allen, Judith A., and Sally L. Kitch. "Disciplined by Disciplines? The Need for an Interdisciplinary Research Mission in Women's Studies." Feminist Studies, "Disciplining Feminism? The Future of Women's Studies," 24.2 (1998): 275-299. Print.

Anheim, Etienne, and Antoine Lilti. "Savoirs de la littérature." Annales. Histoire, Sciences Sociales 65.2 (2010). Print.

Ardis, Ann. "Staging the Public Sphere: Magazine Dialogism and the Prosthetics of Authorship at the Turn of the Twentieth Century." Transatlantic Print Cultures, 1880-1940: Emerging Media, Emerging Modernisms. Ed. Ann Ardis and Patrick Collier. New York: Palgrave Macmillan, 2008. Print.

Best, Stephen, and Sharon Marcus. "Surface Reading: An Introduction." Representations 108.1 (2009): 1-21. Print.

Cottet, Hélène. "American Schools of Interdisciplinarity: History and Literature Programs and Their Early Twentieth-Century Traditions." European Journal of American Studies 1 (2016). Web.

Delahaye, Claire. “'A Tract in Fiction:' Woman Suffrage Literature and the Struggle for the Vote.” European Journal of American Studies 1 (2016). Web.

Deluermoz, Quentin, and Anthony Glinoer. L'insurrection entre histoire et littérature (1789-1914).

Paris: Publications de la Sorbonne, 2015. Print. 
Derail, Agnès, and Bruno Monfort, eds. "L'expérience littéraire de l'histoire en Amérique au XIX ." Revue française d'études américaines 118. 4 (2008). Print.

Dillon, Elizabeth. "Atlantic Practices: Minding the Gap between Literature and History." Early American Literature 43.1 (2008): 205-210. Print.

Dzanouni, Lamia, Hélène Le Dantec-Lowry, and Claire Parfait. "From One Crisis to the Other: History and Literature in The Crisis from 1910 to the early 1920s." European Journal of American Studies 1 (2016). Web.

“Écrire l'histoire.” Littérature 159. 3 (2010). Print.

Fleissner, Jennifer. “Historicism Blues.” American Literary History 25.4 (Winter 2013): 699-717. Print.

Freedgood, Elaine, and Cannon Schmitt. "Denotatively, Technically, Literally." Representations 125. 1 (2014): 1-14. Print.

“Historiens et romanciers. Vies réelles, vies rêvées." Critique 767 (2011). Print.

Jablonka, Ivan. L'Histoire est une littérature contemporaine. Manifeste pour les sciences sociales. Paris: Seuil, 2014. Print.

Jouhaud, Christian, Dinah Ribard, and Nicolas Schapira. Histoire Littérature Témoignage. Paris: Gallimard, 2009. Print.

LaCapra, Dominick. History and Its Limits: Human, Animal, Violence. 2009. Ithaca, NY: Cornell UP, 2016. Print.

---. History, Literature, Critical Theory. Ithaca, NY: Cornell UP, 2013. Print.

“L'histoire saisie par la fiction.”Le Débat165 (2011). Print.

Love, Heather. "Close but not Deep: Literary Ethics and the Descriptive Turn." New Literary History 41.2 (2010): 371-391. Print.

Lyon-Caen, Judith, and Dinah Ribard. L'historien et la littérature. Paris: La Découverte, 2010. Print.

Moretti, Franco. Distant Reading. London: Verso Books, 2012. Print.

Pouly, Marie-Pierre. “Analystes et analyses de la curiosité américaniste des anglicistes en France.” Debates 2010. Nuevo Mundo Mundos Nuevos. Web. Jan. 13, 2010. URL : http://

nuevomundo.revues.org/58502; DOI : 10.4000/nuevomundo.58502

Quanquin, Hélène, and Cécile Roudeau. “A Conversation with Peter Coviello". European Journal of American Studies 11.1 (2016). Web.

Ricoeur, Paul. Freud and Philosophy: An Essay on Interpretation. Trans. Denis Savage. New Haven: Yale UP, 1970. Print.

Slauter, Eric. "History, Literature, and the Atlantic World." Early American Literature 43.1 (2008): 153-186. Print.

\section{NOTES}

i. Hélène Quanquin is associate professor of American Civilization at Université Sorbonne Nouvelle and Cécile Roudeau is professor of American Literature at Université Paris-Diderot.

ii. In History, Literature, Critical Theory, Domick LaCapra uses the phrases "mutually provocative contact" (1) and "intricate and variable forms of interaction" (12). "At issue," he writes, "is how 
best to elaborate a form of inquiry where history and literature are brought into mutually provocative contact-where historical understanding is challenged by critical (including literary) theories, and literary criticism is not only informed but insistently interrogated by historical questions" (1). The rest of the book has a more specific target and is focused on the relation of history and literature (mostly the novel) to extreme violence and exceptional events. LaCapra's theoretical framework, however, detailed in the first chapter entitled "The Mutual Interrogation of History and Literature," remains relevant to our purpose in this special issue. He explains, "I think the most cogent and thought-provoking way to envision that relation, including what might be called the pressure exerted by the historical on the literary, is in terms of intricate and variable forms of interaction, especially modes of mutual interrogation. In other words, history and literature may be seen as posing questions to one another, the answers to which are not foregone conclusions" (12).

iii. This conference was sponsored by some of the most eminent French institutions in the humanities: Ecole des hautes études en sciences sociales, Ecole normale supérieure, Collège de France, University Paris 8-Vincennes-Saint-Denis and Paris Diderot, a sign, arguably, that the question of the boundaries between these two sister disciplines remains an important subject. The argument and program of the conference is available online: http://www.fabula.org/ colloques/sommaire2076.php

Other publications on this contested issue include issues of prominent French journals such as Littérature (2010), Critique (2011), Le Débat (2011). See also Lyon-Caen and Ribard; Jouhaud, Ribard, and Schapira.

iv. "Civilization" is a discipline taught in language studies departments in France. It is an umbrella term that was coined in the 1970s by scholars who did not recognize themselves in literary and linguistic studies, but still valued the study and teaching of history, politics, and society rooted in an interdisciplinary standpoint and textual analyses.

v. On surface reading, see Best and Marcus; Love; and Freedgood and Schmitt. On distant reading, see Moretti. On close reading (and) intellectual history, see also LaCapra, History and Its Limits, especially his defense of close-reading as not always and not necessarily approximating a pious practice or taking the place of the religious, let alone by displacing it (16-17).

\section{AUTHORS}

\section{HÉLÈNE QUANQUIN}

Université Sorbonne Nouvelle

CÉCILE ROUDEAU

Université Paris Diderot 